\title{
Dielektrisitas Lateks Cair dan Lateks Kering (Cup Lumb) serta Karakterisasi Optis Lapisan Tipis Lateks
}

\author{
Mariana B. Malino \\ Jurusan Fisika FMIPA Universitas Tanjungpura Pontianak \\ Jln. Ahmad Yani Pontianak Kalimantan Barat \\ e-mail: mariana.malino9@gmail.com
}

\begin{abstract}
Abtrak
Telah dilakukan penelitian untuk menganalisis dielektrisitas lateks cair dan cup lumb dan serapan optis lapisan tipis lateks. Nilai konstanta dielektrik lateks hasil pengujian berbasis gelombang audio dengan variasi frekuensi, adalah 3,74 untuk lateks cair dan 10,4 untuk cup lumb dengan loss tangent masingmasing 6,12 dan 7,81. Data spektrum UV-Vis dan FT-IR lapisan tipis lateks yang dipreparasi menggunakan teknik spin coating, menunjukkan konsentrasi poli(cis-isoprana) dalam sampel sangat besar.
\end{abstract}

Kata kunci: karet, konstanta dielektrik, spektroskopi UV-Vis, spektroskopi FT-IR, spektrum serapan

\section{Pendahuluan}

Lateks yang bersumber dari getah pohon Hevea braziliensis tersusun atas monomermonomer isoprana dengan komposisi kimia $-\left[\mathrm{C}_{5} \mathrm{H}_{8}\right]_{n}-\quad$ (Ciesielski, 1999). Tabel 1 menunjukkan bahwa partikel karet atau poli(cis-isoprana) dan air merupakan komponen utama dalam lateks. Kandungan air yang besar dalam lateks dapat dipakai untuk menentukan konstanta dielektrik karet. Nilai konstanta dielektrik tersebut selanjutnya dapat dipakai untuk menentukan kualitas karet berdasarkan kadar kering karet, K3 (dry rubber content, DRC) karena nilai loss tangent dan konstanta dielektrik air sama besar dengan nilai loss tangent dan konstanta dielektrik substansi bukan air di dalam lateks (Jayanthy and Sankaranarayanan, 2005; Khalid, 1983).

K3 merupakan salah satu parameter penting penentu kualitas karet karena K3 pada dasarnya menyatakan konsentrasi partikel karet dalam lateks. Nilai K3 lateks segar sangat dipengaruhi oleh tegangan dan usia pohon karet, musim, intensitas penyadapan dan stimulasi kimiawi (Moreno et al, 2005; Zhao et al, 2010). Jadi konsentrasi partikel karet dalam lateks bisa beragam, bergantung pada tempat penanaman dan terutama pada musim sehingga pengukuran spektrum serapan lateks juga sangat penting untuk melihat gugus fungsi kandungan lateks karena spesies-spesies yang terkandung dalam lateks mempengaruhi nilai konstanta dielektrik lateks.
Tabel1 Komposisi lateks (Khalid, 1983; Zhao et al, 2010)

\begin{tabular}{ll}
\hline Kandungan dalam Lateks & Komposisi (\%) \\
\hline Partikel karet & $30,0-40,0$ \\
Protein & $2,00-3,00$ \\
Air & $55,0-65,0$ \\
Glikosida steril & $0,10-0,50$ \\
Resin & $1,50-3,50$ \\
Abu & $0,50-1,00$ \\
Gula & $1,00-2,00$ \\
\hline
\end{tabular}

\section{Metode Penelitian}

Bahan karakterisasi adalah lateks dalam bentuk lateks kering (cup lumb) lateks cair yang diperoleh dari Balai Penelitian Getas, BALITGETAS, Salatiga. Peralatan yang dipakai terdiri atas alat ukur konstanta dielektrik berbasis gelombang audio, spektrofotometer UV-Vis (Milton Roy tipe Spectronic 3000 Array), spektrofotometer FT-IR (Shimadzu tipe IRPrestige-21) dan spin coater.

Lateks cair dipreparasi dengan menambahkan 3 cc amonia ke dalam setiap 600 $\mathrm{ml}$ lateks untuk mencegah pembekuan. Cup lumb dibuat dalam bentuk bulat dengan diameter 3 $\mathrm{cm}$ dan tebal $1 \mathrm{~mm}$. Film tipis lateks dipreparasi dengan mendeposisikan lateks cair di atas substrat kaca menggunakan teknik spin coating pada putaran $2250 \mathrm{rpm}$ selama 1 menit. Skema rangkaian pengukuran loss tangent dan konstanta dielektrik sampel ditunjukkan dalam Gambar 1. Pengukuran dilakukan pada frekuensi 100 hingga $1000 \mathrm{KHz}$ dengan step 100. 


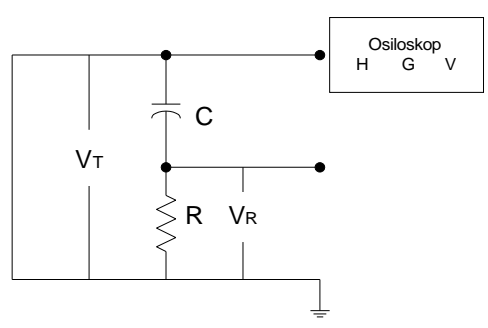

Gambar 1 Set-up eksperimen penentuan konstanta dielektrik

Nilai loss tangent diberikan oleh hubungan:

$$
\tan \delta=\frac{\left(V_{T}^{2}-V_{\theta}^{2}\right)^{1 / 2}}{V_{\theta}}
$$

dengan $\mathrm{V}_{\mathrm{T}}$ adalah amplitudo tegangan pengukuran yang terpasang pada terminal $\mathrm{X}$ osiloskop dan $V_{\theta}=V_{T} \sin (\pi-\phi)=V_{T} \sin \phi$ dengan $\phi$ adalah sudut fase. Lebar lissajous menyatakan $\mathrm{V}_{\theta}$ dan tinggi lissajous (peak to peak) menyatakan $\mathrm{V}_{\mathrm{T}}$.

Konstanta dielektrik kompleks, $\varepsilon^{\prime \prime}$, ditentukan berdasarkan hubungan:

$$
\varepsilon^{\prime \prime}=\frac{V_{\theta} t}{2 \pi f \varepsilon_{o} V_{T} A R}
$$

dengan $\varepsilon_{0}$ adalah permitivitas ruang hampa, $\mathrm{R}$ adalah jejari sampel cup lumb, A adalah luas area plat kapasitor dan $\mathrm{t}$ adalah jarak antara kedua kapasitor.

Nilai konstanta dielektrik diperoleh berdasarkan hubungan:

$$
\varepsilon^{\prime}=\frac{\varepsilon^{\prime \prime}}{\operatorname{tg} \delta}
$$

Pengukuran spektrum serapan lapisan tipis lateks menggunakan spektrofotometer UV-Vis dilakukan pada panjang gelombang 300-200 $\mathrm{cm}^{-1}$ dan untuk spektrofotometer FT-IR, pada rentang $4000-500 \mathrm{~cm}^{-1}$.

\section{Hasil dan Pembahasan}

Hasil perbandingan nilai $V_{\theta}$ terhadap $V_{T}$ cup lumb dan lateks cair ditunjukkan dalam Tabel 2.

Tabel 2. Nilai $V_{\theta}$ terhadap $V_{T}$

\begin{tabular}{llll}
\hline No. & $\mathrm{f}(\mathrm{KHz})$ & $\begin{array}{c}\mathrm{V}_{\theta} / \mathrm{V}_{\mathrm{T}} \\
\text { cup lumb }\end{array}$ & $\begin{array}{c}\mathrm{V}_{\theta} / \mathrm{V}_{\mathrm{T}} \\
\text { lateks cair }\end{array}$ \\
\hline 1 & 100 & 157,5 & 1,27 \\
2 & 200 & 150 & 1,67 \\
3 & 300 & 140 & 2,32 \\
4 & 400 & 135 & 2,59 \\
5 & 500 & 125 & 3,00 \\
6 & 600 & 115 & 3,48 \\
7 & 700 & 110 & 3,72
\end{tabular}

\begin{tabular}{llll}
8 & 800 & 105 & 4,05 \\
9 & 900 & 97.5 & 4,61 \\
10 & 1000 & 92,5 & 5,19 \\
\hline
\end{tabular}

Hasil plot nilai $\left(\mathrm{V}_{\theta} / \mathrm{V}_{\mathrm{T}}\right)$ terhadap frekuensi untuk menentukan gradien, ditunjukkan dalam Gambar 3.
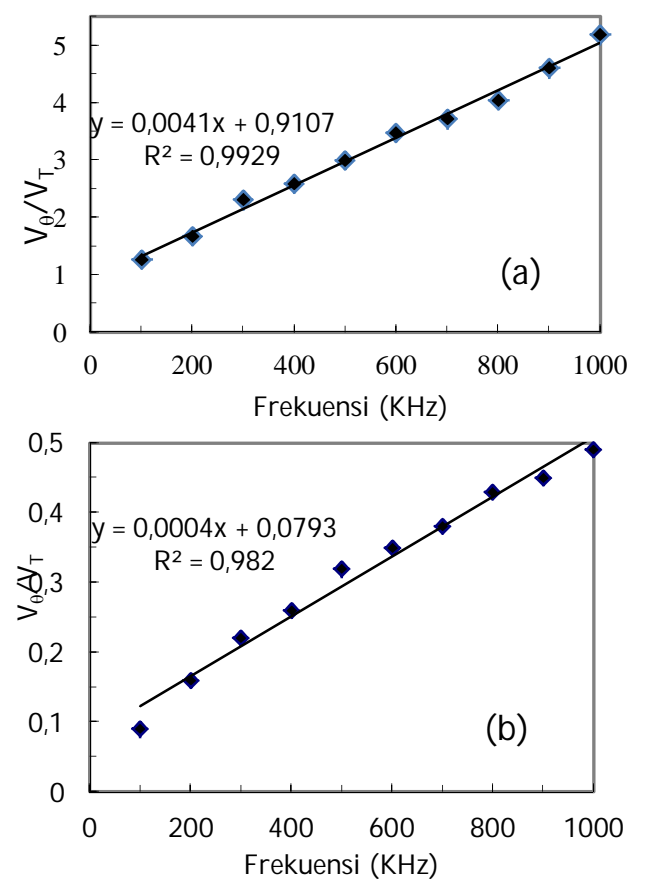

Gambar 3. Hasil plot nilai $\left(\mathrm{V}_{\theta} / \mathrm{V}_{\mathrm{T}}\right)$ terhadap frekuensi untuk a) cup lumb dan b) lateks cair

Berdasarkan persamaan 2 dan Gambar 3a diperoleh nilai $\varepsilon$ " cup lumb sebesar 81,2 dan nilai loss tangent 7,81 pada $100 \mathrm{KHz}$.

Nilai $\varepsilon$ " yang diperoleh untuk lateks cair sebesar 22,9 dan nilai loss tangent 6,12 di frekuensi 100 $\mathrm{KHz}$.

Tabel 3 menunjukkan data nilai konstanta dielektrik cup lumb dan lateks cair beserta hasil dari literatur acuan. Nilai konstanta cup lumb lebih tinggi dibandingkan lateks cair.

\begin{tabular}{|c|c|c|}
\hline $\begin{array}{l}\text { Jenis } \\
\text { Sampel }\end{array}$ & $\begin{array}{c}\text { Konstanta } \\
\text { Dielektrik, }, \varepsilon^{\prime}, \\
\text { Pengukuran }\end{array}$ & $\begin{array}{c}\text { Konstanta } \\
\text { Dielektrik , } \varepsilon^{\prime}, \\
\text { Literatur }\end{array}$ \\
\hline $\begin{array}{l}\text { cup } \\
\text { lumb }\end{array}$ & 10,4 & $\begin{array}{l}7 \text { (Kumar, et al, } \\
2008 \text { ) }\end{array}$ \\
\hline $\begin{array}{l}\text { Lateks } \\
\text { cair }\end{array}$ & 3,74 & $\begin{array}{l}\text { 2,0-2,5; 0,5506 } \\
\text { untuk K3 23,8\% } \\
\text { (Jayanthy and } \\
\text { Sankaranarayanan, } \\
\text { 2005) ; 0.5-2 } \\
\text { (Santulli, et al, } \\
\text { 2004) }\end{array}$ \\
\hline
\end{tabular}

Tabel 3. Konstanta dielektrik sampel hasil pengukuran dan berdasarkan literatur 
Hal tersebut diduga bersumber dari sifat partikel karet yakni poli(cis-)isoprena yang mengandung ikatan ganda karbon. Ikatan ganda karbon pada poli(cis-isoprena) bersifat simetris dan memiliki polarisabilitas yang tinggi sehingga memberikan kontribusi utama bagi nilai konstanta dielektrik cup lumb. Pada lateks cair, molekul air terikat lemah sehingga dengan mudah tersejajarkan oleh medan listrik luar dan sifat dielektrik lateks cair terutama bersumber dari orientasi molekul air.

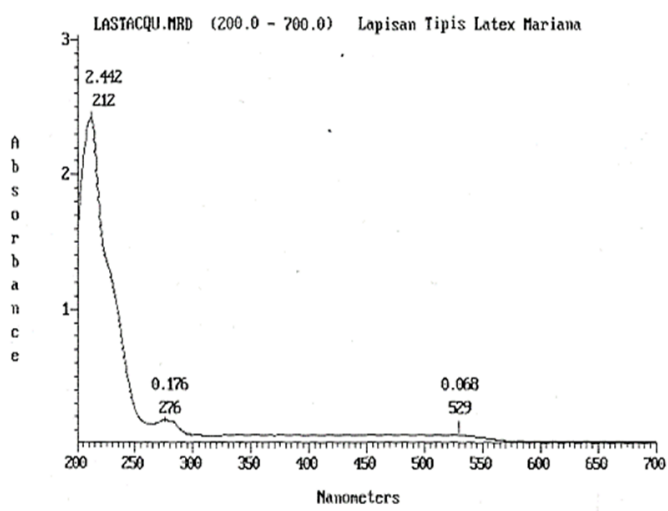

Gambar 4. Spektrum serapan film tipis lateks hasil spektrofotometri UV-Vis

Gambar 4 menunjukkan hasil rekam data spektrum serapan film tipis lateks berdasarkan spektrofotometri UV-Vis yang menunjukkan kesesuaian dengan (Gauglitz and Tuan, 2003).

Ada tiga puncak serapan yakni di $529 \mathrm{~cm}^{-}$ $1,276 \mathrm{~cm}^{-1}$ dan $212 \mathrm{~cm}^{-1}$. Panjang gelombang $212 \mathrm{~cm}^{-1}$ yang terkait dengan energi sebesar 2,442 eV menyatakan gap pita optis lateks yakni hasil transisi pita dari pita ikatan ke pita antiikatan (transisi $\pi-\pi^{*}$ ) di dalam molekul-molekul (cis-)isoprana. Panjang gelombang $276 \mathrm{~cm}^{-1}$ yang bersesuaian dengan energi sebesar 0,176 $\mathrm{eV}$ terkait transisi vibrasional dari ikatan rangkap $\mathrm{CH}_{2}=\mathrm{C}-\mathrm{CH}-\mathrm{CH}_{3}$ dan panjang gelombang $529 \mathrm{~cm}^{-1}$ yang bersesuaian dengan energi sebesar 0,068 eV terkait dengan transisi vibrasional gugus molekul $\mathrm{CH}_{3}$.

Berdasarkan Gambar 5, terlihat sejumlah puncak serapan dari gugus-gugus fungsi konstituen yang terkandung dalam lateks. Poli(cis-isoprana) dapat ditelusuri dari keberadaan gugus $\mathrm{C}-\mathrm{H}, \mathrm{CH}_{2}$ dan $\mathrm{CH}_{3}$. Gugusgugus tersebut menghasilkan puncak-puncak serapan tajam di 2924,09 $\mathrm{cm}^{-1}$ dan 2854,65 cm-1 yang merupakan hasil vibrasi molekul $\mathrm{CH}_{2}$ dan regangan $\mathrm{CH}_{3}$. Kedalaman puncak serapan terkait dengan konsentrasi gugus fungsi molekul-molekul isoprana yang besar.
Puncak-puncak serapan lain yang mengindikasikan keberadaan poli(cis-isoprana) adalah pada panjang gelombang 1658,78 sebagai hasil regangan ikatan ganda $\mathrm{C}=\mathrm{C}$, pada $1450,47 \mathrm{~cm}^{-1}$ dan 1373,32 $\mathrm{cm}^{-1}$ yang merupakan hasil tekukan ikatan $\mathrm{C}-\mathrm{H}$; demikian pula pada panjang gelombang $833,25 \mathrm{~cm}^{-1}$ yang merupakan hasil tekukan luar bidang gugus $\mathrm{C}-\mathrm{H}$. Spesies lain dalam lateks yang menampakkan puncak serapan adalah protein yang diindikasikan oleh keberadaan gugus amida yakni regangan $\mathrm{N}-\mathrm{H}$ yang muncul pada panjang gelombang 3294,42 $\mathrm{cm}^{-1}$. Glikosida yang dicirikan oleh keberadaan ikatan $\mathrm{O}-\mathrm{H}$ diindikasikan muncul pada panjang gelombang $850 \mathrm{~cm}^{-1}$. Gugus fungsi pembangun gula diindikasikan muncul pada panjang gelombang $1543,05 \mathrm{~cm}^{-1}$ dan 1234,44 $\mathrm{cm}^{-1}$. Kemunculan puncak serapan pada panjang gelombang 1087,85 diduga akibat regangan C-O dan regangan $\mathrm{C}-\mathrm{H}$ yang terkandung dalam resin. Sejumlah puncak serapan lemah lain yang belum diverifikasi diduga bersumber dari pengotor yang dapat terkandung dalam lateks. Puncakpuncak serapan akibat regangan $\mathrm{O}-\mathrm{H}$ di sekitar panjang gelombang $3800-3200 \mathrm{~cm}^{-1}$ dan tekukan O-H di sekitar $1700-1600 \mathrm{~cm}^{-1}$ yang mengindikasikan keberadaan air tidak muncul dalam rekaman data FT-IR.

Hal tersebut disebabkan karena molekul air telah dieliminir dari dalam lateks saat casting lateks dalam bentuk film tipis.

\section{Kesimpulan}

Konstanta dielektrik sampel cup lumb dan lateks cair masing-masing sebesar 10,4 dan 3,74 menunjukkan konsentrasi butiran karet yang besar dalam sampel lateks sehingga dapat disimpulkan bahwa lateks yang diperoleh dari BALITGETAS memiliki K3 tinggi (bermutu baik).

Puncak-puncak spektrum hasil analisis UV-Vis sepenuhnya menunjukkan hasil vibrasi molekul-molekul isoprana.

Puncak-puncak serapan tajam pada spektrum FT-IR yang mengindikasikan keberadaan poli(cis-isoprana) menunjukkan konsentrasi butiran karet dalam sampel sangat besar. Data spektrum FT-IR tersebut mendukung hasil penentuan konstanta dielektrik lateks

\section{Ucapan Terima Kasih}

Penulis menyampaikan ucapan terima kasih kepada pihak I-MHERE yang telah mendanai pelaksanaan magang mengenai Karakterisasi Karet di LPPT UGM Yogyakarta 15 November15 Desember 2010 


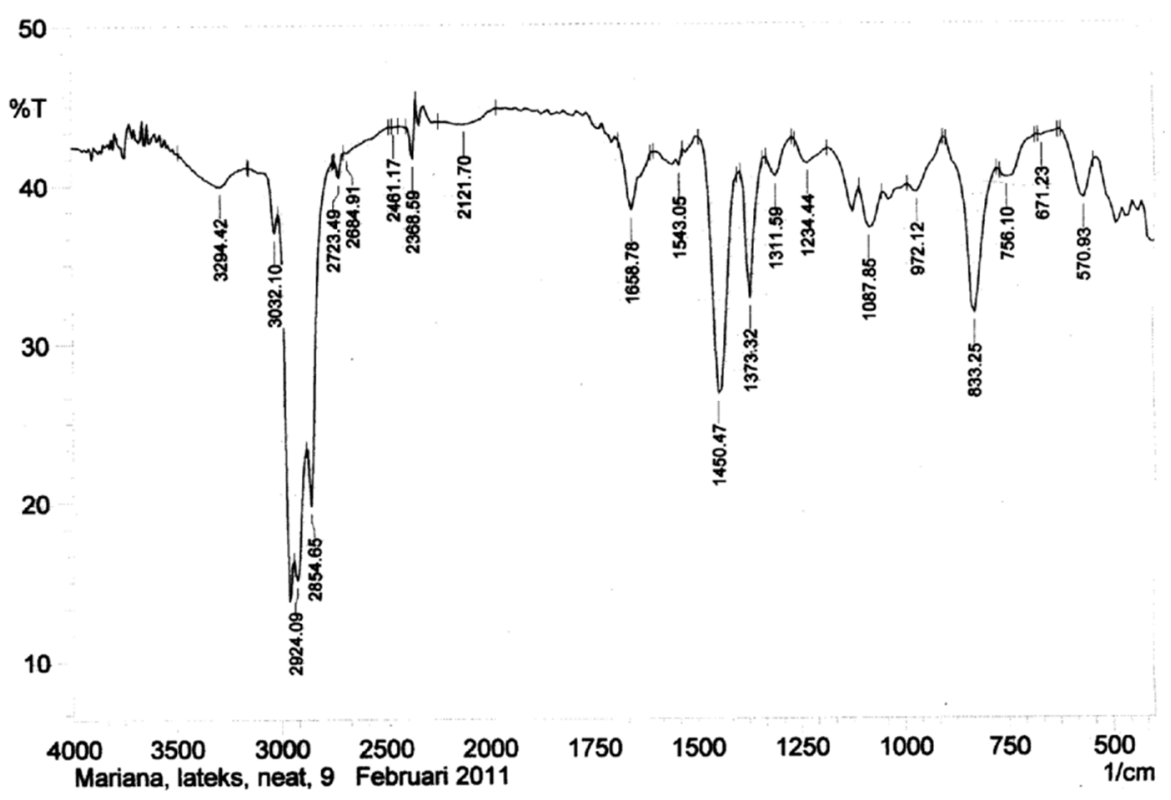

Gambar 5 Spektrum serapan film tipis lateks berdasarkan spektrofotometri FT-IR

\section{Daftar Pustaka}

Ciesielski, Andrew, 1999, Introduction to Rubber Technology, Rapra Technology Limited, UK

Gauglitz,Gunter and Tuan Vo-Dinh, 2003, Handbook of Spectroscopy, Wiley-VCH Verlag GmbH\&Co. KgaA, Weinheim, Germany

Jayanthy, J., P.E. Sankaranarayanan, Measurement of Dry Rubber Content in Latex Using Microwave Technique, Measuerement Science Review, Vol. 5, Section 3(2005)

Khalid, Kaida Bin, Determination of Dry Rubber Content of Hevea Latex by Microwave Technique, Pertanika 5(2),192-195(1982)

Kumar, K. Dinesh and B. Kothandaraman, Modification of (DGEBA) epoxy resin with maleated depolymerised natural rubber, Polymer Letters Vol.2, No.4 p.302311(2008)
Moreno, Rogério Manoel Biagi, Mariselma Ferreira, Paulo de Souza Gonçalves and Luiz Henrique Capparelli Mattoso, Technological Properties of Latex and Natural rubber of Hevea brasiliensisClones, Sci. Agric. (Piracicaba, Braz.), v.62, n.2, p.122-126(2005)

Santulli, C., M. Marzinotto, C. Mazzetti and S. Thomas, 2004, Influence of Content and Diameter of Fibres and Chemical Treatment on the Dielectric Properties of Oil Palm Fibres-Rubber Composites, Science and Engineering of Composite Materials

Zhao, Zhi-min , Xiao-dong Jin, Lin Zhang and Xiao-lei Yu, A Novel Measurement System for Dry Rubber Content in Concentrated Natural Latex Based on Annular Photoelectric Sensor, International Journal of Physical Sciences Vol. 5(3), pp. 251260(2010) 